\title{
SYSTEMATIC REVIEW OF THE EPIDEMIOLOGY OF A SINGLE PHYSICAL TRAUMA AND CANCER
}

Damien M McElvenny a.b*, Alice Davis ${ }^{a}$, Ken Dixonª, Carla Alexandera, Girish Gupta ${ }^{c}$, Ioanna Nixon ${ }^{\mathrm{d}, \mathrm{e}}$, Joanne O Crawforda

aResearch Division, Institute of Occupational Medicine, Edinburgh, UK

${ }^{\mathrm{b}}$ Centre for Occupational and Environmental Health, University of Manchester, Manchester, UK

cUniversity Department of Dermatology, NHS Lothian, Edinburgh, UK

dNHS Greater Glasgow \& Clyde, Glasgow, UK

eSchool of Psychological Sciences and Health, University of Strathclyde, Glasgow, UK

*Address for correspondence:

Prof. D. M. McElvenny PhD

Institute of Occupational Medicine

Research Avenue North

Riccarton

Edinburgh EH14 4AP

Damien.McElvenny@iom-world.org

Tel: +44 (0) 1314498085

Fax: +44 (0) 1314498084 
Twitter: @DamienMcElvenny

Keywords: Single physical trauma; traumatic brain injury; brain cancer; glioma; meningioma

\section{ADDITIONAL INFORMATION}

As this was a systematic review of published data, no ethical approval or consent were required.

Consent to publication is not required as the manuscript contains no personal information.

All the data used in this report are publicly available or can be derived from such.

None of the authors have a conflict of interest.

This study was funded by WorkSafe British Colombia as part of their horizon scanning activity under contract number RS2015-SR02.

Authors' contributions: Damien McElvenny and Joanne Crawford co-led the project. Ken Dixon was responsible for designing and implementing the literature search strategy. Alice Davis and Carla Alexander extracted the data from the included studies, under supervision of Damien McElvenny and Joanne Crawford. Girish Gupta and Ioanna Nixon were responsible for medical input into the interpretation of the findings. All authors were involved in the writing of the final manuscript.

We acknowledge administrative support from Mrs. Marlyn Davis.

Source of Funding: This study was funded by WorkSafe British Colombia as part of their horizon scanning activity under contract number RS2015-SR02. 


\section{BACKGROUND}

34 Physical trauma is defined as a body wound produced by sudden physical injury from 35 impact, violence or accident. The two main types of trauma are blunt force trauma (when 36 an object or force strikes the body, often causing concussions, lacerations or broken 37 bones) and penetrating trauma (when an object pierces the skin or body, creating an 38 open wound). In their landmark review for the US Congress of the causes of cancer, 39 Doll and Peto's only mention of trauma or injury was in relation to cancer of the cervix 40 uteri arising from the trauma of childbirth ${ }^{1}$. A fairly recent editorial that updated their work 41 did not mention either trauma or injury as a cause of cancer ${ }^{2}$. An overview by the 42 International Agency for Research on Cancer (IARC) on preventable exposures 43 associated with human cancers also made no mention of trauma or injury as a cause of 44 cancer $^{3}$.

45 At the outset of our review, concern was expressed by the funders of this research mostly 46 in relation to skin cancer at the site of burns and bone cancer at the site of bony injuries 47 or fractures. The expectation was that, were the epidemiological evidence to be 48 sufficient to determine causality, and the traumatic exposures occurred as a 49 consequence of work, then these cancers might be compensable as work-related.

50 Thus, the aim of this review was to carry out a systematic review of the available literature 51 on trauma or injury and cancer, carrying out meta-analyses where possible, in order to 52 determine whether physical trauma at any age was a cause of cancer. 


\section{MATERIALS AND METHODS}

56 Literature search terms were first trialled by running the searches in online databases.

57 The databases searched and the search terms used for the wider literature search are

58 set out in Table 1. The searches were carried out in June 2016. As well as single 59 physical trauma, the search terms also searched for the traumatic consequences of an 60 assault on the body, such as surgery, but these are not included in this paper. Titles and 61 abstracts were initially screened independently by two reviewers to eliminate those 62 papers not relevant. Those seemingly meeting the inclusion criteria were carried forward 63 for full paper review.

64 The inclusion criteria were epidemiological cohort and case-control studies of primary 65 malignant tumours, where a physical trauma was of interest. There were no age restrictions on the populations studied or language restrictions on the papers identified.

67 Where pooled studies were included, their constituent studies were included, but not 68 included in any meta-analyses to avoid duplication. Ecological and cross-sectional 69 studies were included in the qualitative assessment of the evidence, but case series and 70 case reports were excluded.

71 A data-extraction sheet was developed to include sections on: screening for relevance

72 (include/exclude), including reasons for exclusion; research question(s) being 73 addressed; study specifics (study population, exposure period, case ascertainment, 74 exposure data, factors adjusted for, outcome, results); quality criteria for cohort and case 75 control studies (applied Newcastle-Ottawa scale) ${ }^{4}$; relevant papers identified in the 76 bibliography; and additional notes and comments.

77 Four reviewers from the project team undertook a pilot of the data-extraction sheet with 78 a sample of papers, firstly to test the application of the inclusion/exclusion criteria and 79 secondly to establish if there was consistency in data extraction. The initial testing of the 80 inclusion/exclusion criteria identified only one paper where there was some confusion 81 over inclusion. From this, via discussion, it was identified where the data-extraction 
82 sheet needed slight adaptations. The subsequent testing of the data extraction found no 83 discrepancies and so no further changes were made.

84 The data extraction for each paper was undertaken independently by two reviewers. 85 Through this process the papers identified through initial screening were either included, as they informed the findings of the current review and therefore had their data extracted, or excluded. Where there were inconsistencies in the decision to include or exclude, a third reviewer was consulted and, if this did not lead to consensus, this reviewer's view, which now was also the majority view, was adopted. Figure 1 presents the PRISMA diagram of the study selection process.

91 The Newcastle-Ottawa criteria for cohort and case-control studies ${ }^{4}$, were used to assess 92 study quality, and both scales scored studies on a scale of zero to nine.

93 Where there were a sufficient number of risk estimates, a meta-analysis ${ }^{5}$ was carried out and reporting was according to the MOOSE guidelines ${ }^{6}$. Where relative risks adjusted for confounders were presented, these were preferred to unadjusted risk estimates, as were lagged relative risks that attempted to account for cancer latency. A fixed-effect

97 analysis was carried out in the presence of a lack of statistically significant heterogeneity and, if significant heterogeneity was present, a random-effects analysis was carried out? ${ }^{\text {. }}$

99 The variation attributable to heterogeneity was assessed using the Cochran chi-squared statistic, although it is acknowledged as having limited statistical power ${ }^{8}$.

101 If the outcomes under study are rare in all populations and subgroups under review, one 102 can generally ignore the distinctions among the various measures of relative risk (e.g. 103 odds ratio, rate ratio and risk ratios) ${ }^{9}$. Thus, all effect measures were combined into a 104 single meta-analysis, but as this approach remains controversial they were also analysed 105 separately. An assessment of the robustness of any findings was made by examining 106 important subgroups of the data, for example, cohort and case-control studies examined 107 separately; and the exclusion of lower quality studies (as determined by assessment 
108 using the Newcastle-Ottawa Scale ${ }^{4}$ ). Publication bias was assessed using funnel plots ${ }^{10}$ 109 and Egger's test ${ }^{11}$. All analyses were carried out using the statistical package Stata ${ }^{12}$.

110 


\section{RESULTS}

\section{Brain cancer following traumatic brain injury}

113 The cohort studies are summarised in Table 2 and the case-control studies in Table 3.

114 A total of 5 cohort studies ${ }^{13-17}$ and 16 case-control studies ${ }^{18-33}$ were identified for potential

115 inclusion in the review. Several case-control studies were excluded $18,19,29,31,32$ because

116 they appear in the international case-control studies co-ordinated by the International

117 Agency for Research on $\mathrm{Cancer}^{30}$, and one ${ }^{22}$ because of overlapping coverage with an

118 earlier study ${ }^{13}$ that was deemed to have a larger case coverage, leaving 5 cohort studies

119 and 8 case-control studies that were included in a meta-analysis. The earliest study was

120 published in $1979^{13}$ and the most recent in $2015^{16}$. There was a range of definitions of

121 head trauma. Some studies described a head injury involving loss of consciousness,

122 amnesia or a skull fracture, others relied on a self-reported head injury requiring medical

123 treatment and some simply a traumatic brain injury. Most studies included all brain

124 tumours in the follow-up period whereas some excluded brain cancers occurring less

125 than 12 months since the traumatic brain injury, and other studies seemed to ignore the

126 potential for reverse causality and included all brain cancers occurring after the exposure

127 incident. Other studies used longer latencies to examine the effect. The earlier studies

128 in particular presented analyses unadjusted for potential confounders, although given

129 the lack of knowledge of risk factors for brain cancer, this may not be too problematic.

130 Some presented results for all brain cancers combined and other by diagnostic

131 subgroup, chiefly glioma and meningioma. The relative risks ranged from a potential

132 protective effect with a relative risk of 0.32 for glioma ${ }^{16}$ to a highly statistically significant

133 excess for a relative risk of over 16 for meningioma ${ }^{26}$. Newcastle-Ottawa Scale scores

134 ranged from 2 to 7.

135 For the meta-analysis of all brain cancers combined, a fixed effect analysis gave a meta-

136 relative risk (meta-RR) for all risk estimates combined of 1.15 (95\% confidence interval

$137(\mathrm{Cl}): 1.06$ to 1.25$)$. However, this was in the presence of significant heterogeneity among 
138 all studies $(p<0.001)$ and between cohort and case control studies $(p=0.014)$. The

139 random effects meta-analysis gave a meta-RR for cohort studies of $1.19(95 \% \mathrm{Cl}$ : 0.88

140 to 1.61$)$ and for case-control studies of $1.58(95 \% \mathrm{Cl}: 1.09$ to 2.29$)$. The forest plot for

141 this analysis is shown in Figure 2 and a funnel plot to examine the potential for publication

142 bias is shown in Figure 3. The funnel plot and the Eggar' test $p$-value of 0.47 suggest no

143 strong evidence of publication bias. To examine the robustness of the finding for the

144 case-control studies, each was excluded in turn and the meta-RR re-calculated. Only

145 for the exclusion of one study which had the highest relative risk ${ }^{25}$ did the statistical

146 significance of the meta-RR disappear.

147 In order to further explore the excess found in particular from the case-control studies,

148 separate analyses were carried out for the two main histological subtypes of brain 149 cancer, namely glioma and meningioma. For glioma there was significant heterogeneity 150 between the studies and the random effects analysis gave meta-RRs of $0.96(95 \% \mathrm{Cl}$ : 1510.49 to 1.88$)$ and $1.53(95 \% \mathrm{Cl}: 1.02$ to 2.27$)$ for cohort and case-control studies 152 respectively. Given marginal statistical significance for the case-control studies, it is not 153 surprising that the statistical significance disappears when many of the studies with 154 raised odds ratios are removed in turn from the analysis. For meningioma, there was 155 also statistically significant heterogeneity between studies, with the random effects 156 analysis producing meta-RRs of $1.22(95 \% \mathrm{Cl} 0.95$ to 1.76$)$ and 1.88 (0.84 to 4.19$)$

157 respectively, suggesting that if there exists an excess relative risk, it may not necessarily 158 be restricted to glioma. Thus there is suggestive human epidemiological evidence that 159 traumatic brain injury increases the subsequent risk of developing brain cancer, whether 160 glioma or meningioma.

\section{Malignancies in scars of burns and burns in general}

162 Three population-based cohort studies have examined skin cancer at the site of burns.

163 The Hospital Discharge Register in Denmark was used to identify 18,008 patients with 164 thermal or chemical burns during 1978 to $1993^{34}$. The cohort was linked to the Danish 
165 Cancer Registry, with follow-up to the end of 2002. The standardised incidence ratio $166(\mathrm{SIR})$ for malignant melanoma was $0.7(95 \% \mathrm{Cl}: 0.4$ to 1.1$)$. For squamous cell 167 carcinoma, the SIR was $0.9(95 \% \mathrm{Cl}$ : 0.6 to 1.5$)$ and for basal cell carcinoma it was 0.7 168 (95\% Cl: 0.6 to 0.9$)$. None of these differed materially by sex or age at time of injury. 169 The authors also conducted an analysis of skin cancers confined to the burned area of 170 the body. SIRs were 0.7 for malignant melanoma in men and women, 0.8 and 1.2 171 respectively for squamous cell carcinoma, and 0.7 and 0.8 for basal cell carcinoma, 172 respectively, for all burned sites combined. These risks did not differ materially by the 173 severity of the lesion, or between persons with and without skin transplants.

174 A historical cohort study was conducted in Swedish patients with burn injuries ${ }^{35}$. Using 175 the national Inpatient Registry, 37,095 patients were identified who had been 176 hospitalised for burn injuries. The cohort was linked to the Swedish Cancer Registry for 177 virtually complete follow-up. The SIRs for squamous cell carcinoma and malignant 178 melanoma were not elevated with values of $0.88(95 \% \mathrm{Cl}: 0.70$ to 1.09$)$ and $0.88(95 \% \mathrm{Cl}$ : 1790.69 to 1.12 ) respectively.

180 A population-based retrospective cohort study was carried out using record-linkage 181 systems in Scotland and Australia to investigate the risk of cancer in persons hospitalised 182 with burn injury during 1983 to $2008^{36}$. The cohort consisted of 61,340 persons. This 183 study did not focus on skin cancers at the sites of the burns, but on overall cancer 184 incidence in the cohort. The SIR for malignant melanoma in Western Australia for males 185 and females combined was $0.7(95 \% \mathrm{Cl}: 0.6$ to 0.8$)$ and for Scotland the SIR was 0.8 186 (95\% Cl: 0.6 to 1.1$)$.

187 Thus overall, there is no epidemiological evidence that burns victims are at increased 188 risk of any type of skin cancer, either in general or specifically at the site of the burn.

\section{Osteosarcoma arising from bone injuries}

190 A case-control study of 64 cases aged under 25, and 124 friend and neighbour controls 191 individually-matched on sex, race and birth year was carried out ${ }^{37}$. Questionnaire data 
192 were obtained through telephone interviews with mothers and family physician and 193 school records. Only injuries, and bone conditions requiring attention at least one year 194 before diagnosis were considered. The relative risk for fractures or other bone injuries 195 (presumably such as dislocations, crush Injuries, and bone wounds) at any site was 1.0 196 (95\% Cl: 0.5 to 1.8$)$. For fracture or other bone injury at the tumour sites, the relative 197 risk was 5.5 (95\% Cl: 1.1 to 28.1$)$, based on six cases and three controls. However, 198 none of the injuries among the cases were fractures and there was little data to evaluate 199 the severity of the injury. Thus, there is little epidemiological evidence that bony fractures 200 increase the subsequent risk of bone cancer.

\section{Sinonasal and nasopharyngeal cancers as a result of nose injuries}

202 A population-based case-control study was carried out in the USA ${ }^{38}$. Cases in California 203 were diagnosed with nose, sinus or nasopharyngeal cancer between 1979 and 1985 and 204 were obtained from local tumour registries. Controls were individual matches to cases 205 on age, sex, race and area of residence. The final study included 178 case-control pairs 206 (54 nose, 44 sinus, 82 nasopharynx). Analyses were carried out using conditional 207 logistic regression. The relative risk for nasopharyngeal cancer for a single injury was 2082.2 (95\% Cl: 0.8 to 5.7$)$. For nose cancer the odds ratio was 0.8 (95\% Cl: 0.3 to 2.0$)$ 209 and for sinus cancer was $0.8(95 \% \mathrm{Cl}: 0.2$ to 3.4$)$. Thus, there is no epidemiological 210 evidence that nose injuries increase the risk of subsequent airway tract cancers.

\section{Testicular Cancer following testicular trauma}

212 A case-control study of 271 men with testicular cancer and 259 controls was conducted 213 in the USA ${ }^{39}$. Cases were newly diagnosed between 1976 and 1981 . Controls were 214 patients in the same hospital as the cases, diagnosed with a malignancy other than 215 cancer of the genital tract. It is not clear if they were individually- or frequency-matched. 216 Face-to-face interviews were conducted at the hospital, using a standardised 217 questionnaire. Odds ratios were calculated using the Mantel-Haenszel method, 218 adjusting for the stratification variables and age at diagnosis. The relative risk for study 
219 subjects reporting a history of trauma to the testis was significantly elevated with odds 220 ratio $2.3(95 \% \mathrm{Cl}: 1.3$ to 4.1$)$ and remained elevated when traumas in the two years 221 before cancer diagnosis were removed from the analysis.

222 A descriptive epidemiological study of 1,116 cases of testicular cancer among Australian 223 residents has been carried out ${ }^{40}$. The frequency of recorded history of trauma was $224219 / 782(28 \%)$ with a higher proportion among non-seminomatous germ cell histologies $225(32 \%)$ than among seminoma (25\%) patients. The median interval between trauma and 226 date of diagnosis was 1 year or less, with a range of 0 to 61 years.

227 A population-based case-control study was carried out in Germany including 269 cases 228 and 797 controls $^{41}$. Excluding reports of trauma within 12 months of the index date, the 229 odds ratio for trauma was $2.1(95 \% \mathrm{Cl}: 1.24$ to 3.61$)$. Restricting the analysis to testicular 230 trauma yielded an odds ratio of $3.49(95 \% \mathrm{Cl}: 1.78$ to 6.81$)$. Restricting attention to those 231 episodes where medical attention was sought yields an odds ratio of 0.70 ( 0.19 to 2.63 ).

232 Thus, there is very limited epidemiological evidence that testicular trauma increases the 233 subsequent risk of testicular cancer.

\section{Breast Cancer following breast trauma}

235 A UK case-control study of female breast cancer was carried out during 1996 to $1998^{42}$. 236 Cases were 67 women aged 50-65 with invasive breast carcinoma confirmed by biopsy. 237 Two controls per case were individually matched on age, age of menarche and age of 238 first birth, and were recruited at routine mammography. A short questionnaire was 239 completed giving details of date of birth, age at menarche and menopause, parity and 240 family history of breast cancer. Additional data were collected on life-course events, 241 residential, occupational and reproductive histories, along with lifestyle factors such as 242 smoking, alcohol consumption and stress. The cases reported significantly more 243 physical trauma to the breast in the five years before screening than did the controls. 244 The odds ratio for physical trauma to the breast was $3.3(95 \% \mathrm{Cl}: 1.3$ to 10.8$)$. 
245 A retrospective case-control study was carried out in Jordanian women ${ }^{43}$. Cases were 246 obtained from the Jordanian Cancer Registry for 1996. Of the total sample of 451, 156

247 were dead, 170 could not be traced, 17 were diagnosed before 1996, and 8 refused to 248 participate in the study, leaving 100 cases. A convenience sample of 100 controls 249 matched on age, parity, level of education and place of residence was recruited. A 250 culturally sensitive questionnaire was administered to the cases and controls. Analysis 251 was via logistic regression. Twenty five per cent of the 100 case participants reported 252 trauma to the breast: $21 \%$ more than once. Seventy three per cent reported that the 253 trauma was to the affected breast. Only $6 \%$ of the 100 control participants reported 254 breast trauma. The univariable odds ratio was 5.01 (95\% Cl: 1.97 to 12.96$)$. However, 255 a multivariable model fitted to the data did not include trauma of the breast as a significant 256 risk factor. Thus, there is limited epidemiological evidence that breast trauma is a risk 257 factor for the subsequent development of breast cancer in women. 


\section{DISCUSSION}

261 We believe this is the first wide-ranging review of the epidemiology of single physical 262 trauma and cancer. We found little epidemiological evidence for skin cancer at the site 263 of burns or bone cancer at the site of fractures. We also found little or no evidence for 264 sinonasal and nasopharyngeal cancers as a result of nasal injury, testicular cancer 265 following testicular trauma, and breast cancer following breast trauma. The association 266 for which the evidence was strongest, was for brain cancer, in particular glioma following 267 traumatic brain injury.

268 Overall, there appears to be a lack of aetiological epidemiological studies examining 269 physical trauma and resulting cancer. We updated our search to cover the years 270 following our original search until November 2020 and found no additionally relevant 271 publications. This is in spite of there being interest in trauma as a potential cause of 272 cancer for many decades. For example an editorial in the 1960s states that the issue 273 had been a concern for the medical profession for many years ${ }^{44}$. More recently, a 1980s 274 editorial suggested that trauma had been regularly proposed as an aetiological factor for 275 malignant melanoma for several decades, but made no specific mention of burns ${ }^{45}$.

276 Some of the studies considered in this review did not explicitly exclude the occurrence 277 of multiple trauma episodes to the same site. Also, where relevant, most studies adjust 278 did not adjust for the potential confounding effects of the trauma of undergoing 279 surgery.Glioma is the most common primary intracranial cancer accounting for around $28080 \%$ of all malignant brain cancers ${ }^{46}$, but few established risk factors have been robustly 281 identified ${ }^{47}$. Aside from demographic risk factors such as age and sex, ionising radiation 282 is the only established cause for glioma, although recent evidence suggests that the risk 283 may be higher for meningioma ${ }^{48}$. Few studies adjusted for the potential carcinogenic 284 effects of diagnostic or therapeutic X-ray or CT scans of the brain.

285 There is some evidence that viruses such as cytomegalovirus increase the risk of brain 286 cancer $^{49}$ and allergic conditions may be associated with a reduced risk ${ }^{50}$. Recent 
287 evidence is against obesity and related traits as being significant risk factors for glioma ${ }^{51}$.

288 Mobile phones have not been found to increase the risk of glioma or meningioma ${ }^{52}$ and 289 nor has tobacco smoking ${ }^{53}$.

290 Inflammation plays critical and complex roles after injury. It is needed for healing, but 291 can also lead to complications. Studies of gene activity show that severe injury alters a 292 large number of genes and the extent of the genetic damage varies considerably 293 between individuals ${ }^{54}$. Chronic inflammation, along with the resulting genetic 294 polymorphisms, may thus be associated with an increased cancer risk. Genetic 295 polymorphisms also occur after damage to bones with the potential for an increased 296 cancer risk 55.

297 There was no formal assessment of risk of bias carried out as part of this study, and the 298 Newcastle-Ottawa scale has received some criticism ${ }^{56}$. Many of the studies included in 299 this review, considered physical trauma as one of a number of potential risk factors 300 considered in their analyses. It is notable, that the meta-RR for case-control studies was 301 slightly higher than that for cohort studies, suggesting a possible role for recall bias in 302 elevating the odds ratios for those studies where the participants knew or suspected the 303 hypothesis being investigated. Even if registry data were available, such as those in 304 Trauma Audit and Research Network (TARN) ${ }^{57}$, it would be difficult to isolate a single 305 trauma to relate to a subsequent cancer diagnosis. The variation in the definition of head 306 trauma and a small number of studies dealing with latency further undermines the 307 finding. 


\section{CONCLUSIONS}

310 In conclusion, we found suggestive evidence of an increased risk of brain cancer, mainly

311 in relation to glioma rather than meningioma and recommend that further epidemiological

312 studies, perhaps utilising trauma registries should be carried out. 


\section{REFERENCES}

1. Doll $R$ and Peto $R$. The causes of cancer: quantitative estimates of avoidable risks of cancer in the United States today. J Natl Cancer Inst 1981; 66: 1191-1308. 1981/06/01.

2. Rothenberg R. The causes of cancer, revisited. Annals of Epidemiology 2015; 25: 215-216. DOI: https://doi.org/10.1016/j.annepidem.2014.11.012.

3. Cogliano VJ, Baan R, Straif $\mathrm{K}$, et al. Preventable exposures associated with human cancers. Journal of the National Cancer Institute 2011; 103: 1827-1839. 2011/12/12. DOI: 10.1093/jnci/djr483.

4. Wells G, Shea B, O'Connell D, et al. The Newcastle-Ottawa Scale (NOS) for assessing the quality of nonrandomized studies in meta-analyses. 2013.

5. Glass GV. Primary, Secondary, and Meta-Analysis of Research. Educational Researcher 1976; 5: 3-8. DOI: 10.2307/1174772.

6. Stroup DF, Berlin JA, Morton SC, et al. Meta-analysis of Observational Studies in EpidemiologyA Proposal for Reporting. JAMA 2000; 283: 20082012. DOI: $10.1001 /$ jama.283.15.2008.

7. DerSimonian R and Laird N. Meta-analysis in clinical trials. Controlled Clinical Trials 1986; 7: 177-188. DOI: https://doi.org/10.1016/01972456(86)90046-2.

8. Higgins JPT, Thompson SG, Deeks JJ, et al. Measuring inconsistency in meta-analyses. BMJ 2003; 327: 557-560. DOI: $10.1136 / \mathrm{bmj} .327 .7414 .557$.

9. Greenland S. Quantitative methods in the review of epidemiogic literature Epidemiologic Reviews 1987; 9: 1-30. DOI: 10.1093/oxfordjournals.epirev.a036298.

10. Sterne JAC, Sutton AJ, Ioannidis JPA, et al. Recommendations for examining and interpreting funnel plot asymmetry in meta-analyses of randomised controlled trials. BMJ 2011; 343: d4002. DOI: 10.1136/bmj.d4002.

11. Egger M, Smith GD, Schneider $M$, et al. Bias in meta-analysis detected by a simple, graphical test. BMJ 1997; 315: 629-634. DOI: 10.1136/bmj.315.7109.629.

12. Statacorp. Stata Statistical Software: Release 13. College Station, TX: Statacorp LP, 2013.

13. Annegers JF, Laws ER, Jr., Kurland LT, et al. Head Trauma and Subsequent Brain Tumors. Neurosurgery 1979; 4: 203-206. DOI: 10.1227/00006123-197903000-00001.

14. Chen $\mathrm{YH}$, Keller JJ, Kang JH, et al. Association between traumatic brain injury and the subsequent risk of brain cancer. J Neurotrauma 2012; 29: 1328-1333. 2012/02/11. DOI: 10.1089/neu.2011.2235.

15. Inskip PD, Mellemkjaer L, Gridley G, et al. Incidence of intracranial tumors following hospitalization for head injuries (Denmark). Cancer Causes Control 1998; 9: 109-116. 1998/03/05.

16. Munch TN, Gørtz S, Wohlfahrt J, et al. The long-term risk of malignant astrocytic tumors after structural brain injury--a nationwide cohort study. Neuro Oncol 2015; 17: 718-724. 2014/11/21. DOI: $10.1093 /$ neuonc/nou312. 
17. Nygren C, Adami J, Ye W, et al. Primary brain tumors following traumatic brain injury--a population-based cohort study in Sweden. Cancer Causes Control 2001; 12: 733-737. 2001/09/20.

18. Ahlbom A, Navier I, Norrell S, et al. Nonoccupational risk indicators for atrocytoma in adults. American Journal of Epidemiology 1986; 124 : 334-337. DOI: $10.1093 /$ oxfordjournals.aje.a114393.

19. Burch JD, Craib KJ, Choi BC, et al. An exploratory case-control study of brain tumors in adults. J Natl Cancer Inst 1987; 78: 601-609. 1987/04/01. 20. Carpenter AV, Flanders WD, Frome EL, et al. Brain cancer and nonoccupational risk factors: a case-control study among workers at two nuclear facilities. Am J Public Health 1987; 77: 1180-1182. DOI: 10.2105/ajph.77.9.1180.

21. Choi N, Sschuman L and Gullen W. Epidemiology of primary central nervpous system neoplasms: II: Case-control study. American Journal of Epidemiology 1970; 91: 467-485. DOI: 10.1093/oxfordjournals.aje.a121158.

22. Codd MB, Kurland LT, O'Fallon WM, et al. Case-Control Study of Neuroepithelial Tumors in Rochester, Minnesota, 1950-1977. Neuroepidemiology 1990; 9: 17-26. DOI: 10.1159/000110748.

23. Gousias K, Markou M, Voulgaris S, et al. Descriptive Epidemiology of Cerebral Gliomas in Northwest Greece and Study of Potential Predisposing Factors, 2005-2007. Neuroepidemiology 2009; 33: 89-95. DOI: $10.1159 / 000222090$.

24. Hochberg $F$, Toniolo $P$ and Cole $P$. Head trauma and seizures as risk factors of glioblastoma. Neurology 1984; 34: 1511-1514. 1984/11/01. DOI: 10.1212/wnl.34.11.1511.

25. Hu J, Johnson KC, Mao Y, et al. Risk factors for glioma in adults: a case-control study in northeast China. Cancer Detect Prev 1998; 22: 100108. 1998/04/17.

26. Hu J, Little J, Xu T, et al. Risk factors for meningioma in adults: A casecontrol study in northeast China. International Journal of Cancer 1999; 83: 299-304. DOI: 10.1002/(sici)1097-0215(19991029)83:3<299: :aidijc2 >3.0.co;2-z.

27. Monteiro GTR, Pereira RA, Koifman RJ, et al. Head injury and brain tumours in adults: A case-control study in Rio de Janeiro, Brazil. European Journal of Cancer 2006; 42: 917-921. DOI: https://doi.org/10.1016/j.ejca.2005.11.028.

28. Preston-Martin S, Mack W and Henderson BE. Risk Factors for Gliomas and Meningiomas in Males in Los Angeles County. Cancer Research 1989; 49: 6137-6143.

29. Preston-Martin S, Paganini-Hill A, Henderson BE, et al. Case-control study of intracranial meningiomas in women in Los Angeles County, California. J Natl Cancer Inst 1980; 65: 67-73. 1980/07/01.

30. Preston-Martin S, Pogoda JM, Schlehofer B, et al. An international casecontrol study of adult glioma and meningioma: the role of head trauma. International Journal of Epidemiology 1998; 27: 579-586. DOI: 10.1093/ije/27.4.579.

31. Preston-Martin S, Yu MC, Henderson BE, et al. Risk factors for meningiomas in men in Los Angeles County. J Natl Cancer Inst 1983; 70: 863-866. 1983/05/01. 
32. Schlehofer B, Blettner $M$, Becker $N$, et al. Medical risk factors and the development of brain tumors. Cancer 1992; 69: 2541-2547. 1992/05/15. DOI: 10.1002/1097-0142(19920515)69:10<2541: :aidcncr2820691025>3.0.co;2-h.

33. Zampieri P, Meneghini F, Grigoletto F, et al. Risk factors for cerebral glioma in adults: a case-control study in an Italian population. $J$ Neurooncol 1994; 19: 61-67. 1994/01/01.

34. Mellemkjaer L, Hölmich LR, Gridley G, et al. Risks for Skin and Other Cancers Up to 25 Years After Burn Injuries. Epidemiology 2006; 17: 668-673. DOI: 10.1097/01.ede.0000239651.06579.a4.

35. Lindelof B, Krynitz B, Granath F, et al. Burn injuries and skin cancer: a population-based cohort study. Acta Derm Venereol 2008; 88: 20-22. 2008/01/08. DOI: 10.2340/00015555-0339.

36. Duke JM, Bauer J, Fear MW, et al. Burn injury, gender and cancer risk: population-based cohort study using data from Scotland and Western Australia. BMJ Open 2014; 4: e003845. DOI: 10.1136/bmjopen-2013003845.

37. Operalski E, Preston-Martin S, Henderson B, et al. A case-control study of osteosarcoma in young persons. American Journal of Epidemiology 1987; 126: 118-126. DOI: 10.1093/oxfordjournals.aje.a114643.

38. Assraf-Goral A. Nasal conditions and diet as etiologic risk factors for nasal cancers among non-Asians in Los Angeles County and San Francisco Bay areas. University of California, Los Angeles, 1996.

39. Brown LM, Pottern LM and Hoover RN. Testicular cancer in young men: the search for causes of the epidemic increase in the United States. $J$ Epidemiol Community Health 1987; 41: 349-354. DOI: 10.1136/jech.41.4.349.

40. Stone JM, Cruickshank DG, Sandeman TF, et al. Laterality, maldescent, trauma and other clinical factors in the epidemiology of testis cancer in Victoria, Australia. $\mathrm{Br} J$ Cancer 1991; 64: 132-138. DOI: 10.1038/bjc.1991.256.

41. Merzenich $\mathrm{H}$, Ahrens $\mathrm{W}$, Stang $A$, et al. Sorting the hype from the facts in testicular cancer: is testicular cancer related to trauma? J Urol 2000; 164 : 2143-2144. 2000/11/04.

42. Rigby JE, Morris JA, Lavelle J, et al. Can physical trauma cause breast cancer? European Journal of Cancer Prevention 2002; 11: 307-311.

43. Petro-Nustas W, Norton ME and Al-Masarweh I. Risk Factors for Breast Cancer in Jordanian Women. Journal of Nursing Scholarship 2002; 34: 1925. DOI: $10.1111 / \mathrm{j} .1547-5069.2002 .00019 . x$.

44. Anon. The Role of Trauma in Cancer. Radiology 1963; 81: 1039-1041. DOI: $10.1148 / 81.6 .1039$.

45. Briggs JC. The role of trauma in the aetiology of malignant melanoma: a review article. $B r \mathrm{~J}$ Plast Surg 1984; 37: 514-516. 1984/10/01. DOI: 10.1016/0007-1226(84)90141-3.

46. Ostrom QT, Gittleman H, Farah $P$, et al. CBTRUS statistical report: Primary brain and central nervous system tumors diagnosed in the United States in 2006-2010. Neuro Oncol 2013; 15 Suppl 2: ii1-ii56. DOI: 10.1093/neuonc/not151. 
47. Ostrom QT, Bauchet L, Davis FG, et al. The epidemiology of glioma in adults: a "state of the science" review. Neuro Oncol 2014; 16: 896-913. DOI: $10.1093 /$ neuonc/nou087.

48. Braganza MZ, Kitahara CM, Berrington de González A, et al. Ionizing radiation and the risk of brain and central nervous system tumors: $a$ systematic review. Neuro Oncol 2012; 14: 1316-1324. 2012/09/05. DOI: $10.1093 /$ neuonc/nos208.

49. Söderberg-Nauclér $C$ and Johnsen JI. Cytomegalovirus infection in brain tumors: A potential new target for therapy? Oncoimmunology 2012; 1 : 739-740. DOI: 10.4161/onci.19441.

50. Wigertz A, Lönn S, Schwartzbaum J, et al. Allergic Conditions and Brain Tumor Risk. American Journal of Epidemiology 2007; 166: 941-950. DOI: 10.1093/aje/kwm203.

51. Disney-Hogg L, Sud A, Law PJ, et al. Influence of obesity-related risk factors in the aetiology of glioma. $B r \mathrm{~J}$ Cancer 2018; 118: 1020-1027. 2018/03/13. DOI: 10.1038/s41416-018-0009-x.

52. Group TIS. Brain tumour risk in relation to mobile telephone use: results of the INTERPHONE international case-control study. International Journal of Epidemiology 2010; 39: 675-694. DOI: 10.1093/ije/dyq079.

53. Vida S, Richardson L, Cardis E, et al. Brain tumours and cigarette smoking: analysis of the INTERPHONE Canada case-control study. Environ Health 2014; 13: 55-55. DOI: 10.1186/1476-069X-13-55.

54. Bennett ER, Reuter-Rice K and Laskowitz DT. Frontiers in Neuroscience Genetic Influences in Traumatic Brain Injury. In: Laskowitz D and Grant G (eds) Translational Research in Traumatic Brain Injury. Boca Raton (FL): CRC Press/Taylor and Francis Group

(C) 2016 by Taylor \& Francis Group, LLC., 2016.

55. Del Buono A, Denaro V and Maffulli N. Genetic susceptibility to aseptic loosening following total hip arthroplasty: a systematic review. Br Med Bull 2012; 101: 39-55. 2011/06/10. DOI: 10.1093/bmb/ldr011.

56. Stang A. Critical evaluation of the Newcastle-Ottawa scale for the assessment of the quality of nonrandomized studies in meta-analyses. Eur $\mathrm{J}$ Epidemiol 2010; 25: 603-605. 2010/07/24. DOI: 10.1007/s10654-0109491-z.

57. Dixon JR, Lecky F, Bouamra O, et al. Age and the distribution of major injury across a national trauma system. Age Ageing 2020; 49: 218-226. 2019/11/26. DOI: 10.1093/ageing/afz151. 
Table 1 - Databases searched and search terms

NIOSHTIC-2, OLDMEDLINE and ProQuest Dialog Healthcare databases were searched including Current Contents; BIOSIS; ProQuest Dissertations and Theses Professional; EMBASE; MEDLINE; Scisearch; and Psychinfo.

The search string used for the above bibliographic databases was: (trauma OR injury OR hurt OR wound OR wounding OR sore OR bruise OR cut OR laceration OR lesion OR abrasion OR contusion OR "heat trauma" OR "cold trauma" OR "UV trauma" OR "noise trauma" OR "multiple trauma exposures" OR "chemical trauma" OR "heat strokes" OR (exposure AND wind) OR (exposure AND solar) OR burn OR fracture) AND (cancer OR neoplasm OR neoplasms OR tumour OR tumours OR tumour AND ("systematic review" OR review OR "cohort study" OR "case-control study" OR "case-referent study" OR meta-analysis OR "cross-sectional-study" OR "ecological study")

The Cochrane Database of Systematic Reviews (CDSR) and Database of Abstracts on Reviews of Effects (DARE) were searched using the search string: trauma AND cancer.

Grey literature searches were carried out in Google; Google Scholar; New York Academy of Medicine's Grey Literature Report; and Open Grey. 


Web site Searches were undertaken using the following web sites: IARC; Cancer Research UK; NCI; CDC; IOSH; WHO; CCSRI;
Canadian Cancer Society; BC Cancer Agency; and Australian Cancer Research. The search string used was (trauma OR injury OR
wound) AND cancer AND epidemiology.


Table 2 - Cohort studies of brain cancer following traumatic brain injury

\begin{tabular}{|c|c|c|c|c|c|c|c|}
\hline Reference & Study Type & $\begin{array}{l}\text { Study } \\
\text { Population }\end{array}$ & Traumatic event & $\begin{array}{l}\text { Exposure } \\
\text { Period }\end{array}$ & $\begin{array}{l}\text { Factors accounted } \\
\text { for in analysis }\end{array}$ & $\begin{array}{l}\text { RR }(95 \% \mathrm{Cl} \text {, } \\
\text { number of } \\
\text { (exposed) } \\
\text { cases) }\end{array}$ & $\begin{array}{l}\text { Quality } \\
\text { Score } \\
\text { (NOS) }\end{array}$ \\
\hline $\begin{array}{l}\text { Annegers et } \\
\text { al, } 1979^{13}\end{array}$ & $\begin{array}{l}\text { Retrospective } \\
\text { cohort study of } \\
\text { patients }\end{array}$ & $\begin{array}{l}2,953 \text { survivors } \\
\text { of significant } \\
\text { head trauma }\end{array}$ & $\begin{array}{l}\text { Head injury with } \\
\text { brain involvement } \\
\text { manifested by loss } \\
\text { of consciousness, } \\
\text { amnesia or skull } \\
\text { fracture }\end{array}$ & 1935 to 1974 & $\begin{array}{l}\text { Age, sex, calendar } \\
\text { year }\end{array}$ & $\begin{array}{l}\text { All brain } 1.0(0.3 \\
\text { to } 2.6,4) \\
\text { Glioma } 0.7(0.0 \\
\text { to } 5.6,1) \\
\text { Meningioma } 1.6 \\
(0.3 \text { to } 4.7,3)\end{array}$ & 6 \\
\hline
\end{tabular}




\begin{tabular}{|c|c|c|c|c|c|c|c|}
\hline Reference & Study Type & $\begin{array}{l}\text { Study } \\
\text { Population }\end{array}$ & Traumatic event & $\begin{array}{l}\text { Exposure } \\
\text { Period }\end{array}$ & $\begin{array}{l}\text { Factors accounted } \\
\text { for in analysis }\end{array}$ & $\begin{array}{l}\text { RR }(95 \% \mathrm{Cl} \text {, } \\
\text { number of } \\
\text { (exposed) } \\
\text { cases) }\end{array}$ & $\begin{array}{l}\text { Quality } \\
\text { Score } \\
\text { (NOS) }\end{array}$ \\
\hline $\begin{array}{l}\text { Inskip et al, } \\
1998^{15}\end{array}$ & $\begin{array}{l}\text { Retrospective } \\
\text { cohort study of } \\
\text { patients }\end{array}$ & $\begin{array}{l}228,055 \\
\text { patients in } \\
\text { Denmark } \\
\text { hospitalised } \\
\text { because of } \\
\text { concussion, } \\
\text { fractured skull } \\
\text { or other head } \\
\text { injury }\end{array}$ & $\begin{array}{l}\text { Fractured skull, } \\
\text { concussion or } \\
\text { cerebral laceration } \\
\text { or contusion }\end{array}$ & 1977 to 1992 & $\begin{array}{l}\text { Age, sex, calendar } \\
\text { year }\end{array}$ & $\begin{array}{l}>1 \text { year since } \\
\text { discharge } \\
\text { Intracranial } \\
\text { tumours } 1.1(1.0 \\
\text { to } 1.3,199) \\
\text { Glioma } 1.0(0.8 \\
\text { to } 1.2,79) \\
\text { Meningioma } 1.2 \\
(0.8 \text { to } 1.7,30)\end{array}$ & 6 \\
\hline
\end{tabular}




\begin{tabular}{|c|c|c|c|c|c|c|c|}
\hline Reference & Study Type & $\begin{array}{l}\text { Study } \\
\text { Population }\end{array}$ & Traumatic event & $\begin{array}{l}\text { Exposure } \\
\text { Period }\end{array}$ & $\begin{array}{l}\text { Factors accounted } \\
\text { for in analysis }\end{array}$ & $\begin{array}{l}\text { RR }(95 \% \mathrm{Cl} \text {, } \\
\text { number of } \\
\text { (exposed) } \\
\text { cases) }\end{array}$ & $\begin{array}{l}\text { Quality } \\
\text { Score } \\
\text { (NOS) }\end{array}$ \\
\hline $\begin{array}{l}\text { Nygren et al, } \\
2001^{17}\end{array}$ & $\begin{array}{l}\text { Retrospective } \\
\text { cohort study of } \\
\text { patients }\end{array}$ & $\begin{array}{l}311,006 \\
\text { patients } \\
\text { hospitalised for } \\
\text { traumatic brain } \\
\text { injury }\end{array}$ & Skull trauma & 1965 to 1994 & $\begin{array}{l}\text { Age, sex, calendar } \\
\text { year }\end{array}$ & $\begin{array}{l}>1 \text { year since } \\
\text { discharge } \\
\text { Primary brain } \\
\text { cancer } 1.0(0.8 \\
\text { to } 1.1,161)\end{array}$ & 6 \\
\hline
\end{tabular}




\begin{tabular}{|c|c|c|c|c|c|c|c|}
\hline Reference & Study Type & $\begin{array}{l}\text { Study } \\
\text { Population }\end{array}$ & Traumatic event & $\begin{array}{l}\text { Exposure } \\
\text { Period }\end{array}$ & $\begin{array}{l}\text { Factors accounted } \\
\text { for in analysis }\end{array}$ & $\begin{array}{l}\mathrm{RR}(95 \% \mathrm{Cl}, \\
\text { number of } \\
\text { (exposed) } \\
\text { cases) }\end{array}$ & $\begin{array}{l}\text { Quality } \\
\text { Score } \\
\text { (NOS) }\end{array}$ \\
\hline $\begin{array}{l}\text { Chen et al, } \\
2012^{14}\end{array}$ & $\begin{array}{l}\text { Retrospective } \\
\text { cohort study of } \\
\text { patients and a } \\
\text { comparison } \\
\text { cohort matched } \\
\text { on age, sex and } \\
\text { index year }\end{array}$ & $\begin{array}{l}5,007 \text { patients } \\
\text { who had visited } \\
\text { ambulatory } \\
\text { care centres or } \\
\text { had been } \\
\text { hospitalised } \\
\text { with a } \\
\text { diagnosis of } \\
\text { TBI and } 25,035 \\
\text { controls } \\
\text { randomly } \\
\text { selected from a } \\
\text { national health } \\
\text { insurance }\end{array}$ & $\begin{array}{l}\text { Traumatic brain } \\
\text { injury }\end{array}$ & 2001 to 2002 & $\begin{array}{l}\text { Geographic location, } \\
\text { urbanisation, monthly } \\
\text { income }\end{array}$ & $\begin{array}{l}\text { The RR of brain } \\
\text { cancer within } 3 \\
\text { years of follow- } \\
\text { up was } 4.67 \\
(1.84 \text { to } 11.83,9) \\
\text { for the TBI } \\
\text { versus non-TBI } \\
\text { cohort. }\end{array}$ & 7 \\
\hline
\end{tabular}

$-25-$ 


\begin{tabular}{|c|c|c|c|c|c|c|c|}
\hline Reference & Study Type & $\begin{array}{l}\text { Study } \\
\text { Population }\end{array}$ & Traumatic event & $\begin{array}{l}\text { Exposure } \\
\text { Period }\end{array}$ & $\begin{array}{l}\text { Factors accounted } \\
\text { for in analysis }\end{array}$ & $\begin{array}{l}\text { RR (95\% Cl, } \\
\text { number of } \\
\text { (exposed) } \\
\text { cases) }\end{array}$ & $\begin{array}{l}\text { Quality } \\
\text { Score } \\
\text { (NOS) }\end{array}$ \\
\hline & & $\begin{array}{l}\text { research } \\
\text { database }\end{array}$ & & & & & \\
\hline $\begin{array}{l}\text { Munch et al, } \\
2015^{16}\end{array}$ & $\begin{array}{l}\text { Retrospective } \\
\text { cohort study of } \\
\text { patients with TBI } \\
\text { and the general } \\
\text { population }\end{array}$ & $\begin{array}{l}48,194 \text { patients } \\
\text { with a } \\
\text { traumatic brain } \\
\text { injury }\end{array}$ & TBI & 1978 to 2001 & $\begin{array}{l}\text { Age, sex, calendar } \\
\text { year }\end{array}$ & $\begin{array}{l}\text { Glioma } 1-4 \text { years } \\
\text { after TBI } 1.99 \\
(1.00 \text { to } 3.50,10) \\
\text { Glioma } 5+\text { years } \\
\text { after TBI } 0.32 \\
(0.10 \text { to } 0.75,4)\end{array}$ & 6 \\
\hline
\end{tabular}


Table 3 - Case-control studies of brain cancer following traumatic brain injury

\begin{tabular}{|c|c|c|c|c|c|c|c|}
\hline Reference & Study Type & $\begin{array}{l}\text { Study } \\
\text { Population }\end{array}$ & Traumatic event & $\begin{array}{l}\text { Case } \\
\text { ascertainment }\end{array}$ & $\begin{array}{l}\text { Factors } \\
\text { accounted for in } \\
\text { analysis }\end{array}$ & $\begin{array}{l}\text { RR }(95 \% \mathrm{Cl} \text {, } \\
\text { number of } \\
\text { (exposed) } \\
\text { cases) }\end{array}$ & $\begin{array}{l}\text { Quality } \\
\text { Score } \\
\text { (NOS) }\end{array}$ \\
\hline $\begin{array}{l}\text { Choi et al, } \\
1970^{21}\end{array}$ & $\begin{array}{l}\text { Retrospective } \\
\text { hospital-based } \\
\text { case-control } \\
\text { study }\end{array}$ & $\begin{array}{l}157 \text { central } \\
\text { nervous system } \\
\text { cancer cases; } \\
157 \text { hospital- } \\
\text { matched controls } \\
\text { with condition } \\
\text { other than } \\
\text { cancer, } \\
\text { neurologic, } \\
\text { ophthalmic or } \\
\text { lymphatic } \\
\text { condition. } \\
\text { Matching }\end{array}$ & $\begin{array}{l}\text { Brain injury such as } \\
\text { fractured skull } \\
\text { unconsciousness, } \\
\text { or bleeding from } \\
\text { the head requiring } \\
\text { hospitalisation } \\
\text { and/or operation }\end{array}$ & 1963 to 1964 & None & $\begin{array}{l}\text { All brain } 0.84 \\
\text { (0.32 to } 2.20 \text {, } \\
8 \text { ) } \\
\text { All glioma } 1.34 \\
(0.35 \text { to } 5.21 \text {, } \\
5) \\
\text { Meningioma } \\
0.52 \text { (0.04 to } \\
6.22,1) \\
\text { [Not provided } \\
\text { in the paper, } \\
\text { so calculated } \\
\text { using }\end{array}$ & 3 \\
\hline
\end{tabular}




\begin{tabular}{|c|c|c|c|c|c|c|c|}
\hline Reference & Study Type & $\begin{array}{l}\text { Study } \\
\text { Population }\end{array}$ & Traumatic event & $\begin{array}{l}\text { Case } \\
\text { ascertainment }\end{array}$ & $\begin{array}{l}\text { Factors } \\
\text { accounted for in } \\
\text { analysis }\end{array}$ & $\begin{array}{l}\mathrm{RR}(95 \% \mathrm{Cl} \text {, } \\
\text { number of } \\
\text { (exposed) } \\
\text { cases) }\end{array}$ & $\begin{array}{l}\text { Quality } \\
\text { Score } \\
\text { (NOS) }\end{array}$ \\
\hline & & $\begin{array}{l}\text { variables } \\
\text { included hospital, } \\
\text { sex, age, race, } \\
\text { area of residence } \\
\text { and urban status. }\end{array}$ & & & & $\begin{array}{l}\text { unmatched } \\
\text { method] }\end{array}$ & \\
\hline $\begin{array}{l}\text { Preston-Martin } \\
\text { et al, } 1980^{29}\end{array}$ & $\begin{array}{l}\text { Population- } \\
\text { based case- } \\
\text { control study }\end{array}$ & $\begin{array}{l}185 \text { women with } \\
\text { intracranial } \\
\text { meningioma and } \\
185 \\
\text { neighbourhood } \\
\text { controls matched } \\
\text { on sex, age and } \\
\text { race }\end{array}$ & $\begin{array}{l}\text { Medically treated } \\
\text { head trauma }\end{array}$ & 1972 to 1975 & $\begin{array}{l}\text { Results } \\
\text { unadjusted, but an } \\
\text { additional analysis } \\
\text { adjusting for head } \\
\text { X-rays didn't alter } \\
\text { findings }\end{array}$ & $\begin{array}{l}\text { RR } 2.0 \text { (1.2 to } \\
3.5, \text { not stated) }\end{array}$ & 4 \\
\hline
\end{tabular}




\begin{tabular}{|c|c|c|c|c|c|c|c|}
\hline Reference & Study Type & $\begin{array}{l}\text { Study } \\
\text { Population }\end{array}$ & Traumatic event & $\begin{array}{l}\text { Case } \\
\text { ascertainment }\end{array}$ & $\begin{array}{l}\text { Factors } \\
\text { accounted for in } \\
\text { analysis }\end{array}$ & $\begin{array}{l}\text { RR }(95 \% \mathrm{Cl} \text {, } \\
\text { number of } \\
\text { (exposed) } \\
\text { cases) }\end{array}$ & $\begin{array}{l}\text { Quality } \\
\text { Score } \\
\text { (NOS) }\end{array}$ \\
\hline $\begin{array}{l}\text { Preston-Martin } \\
\text { et al, } 1983^{31}\end{array}$ & $\begin{array}{l}\text { Population- } \\
\text { based case- } \\
\text { control study }\end{array}$ & $\begin{array}{l}105 \text { men with } \\
\text { intracranial } \\
\text { meningioma and } \\
105 \\
\text { neighbourhood } \\
\text { controls matched } \\
\text { on sex, age and } \\
\text { race }\end{array}$ & $\begin{array}{l}\text { Serious head injury } \\
\text { and/or boxing }\end{array}$ & 1972 to 1979 & Results unadjusted & $\begin{array}{l}\text { RR } 1.9 \text { (1.1 to } \\
3.2,40)\end{array}$ & 4 \\
\hline $\begin{array}{l}\text { Hochberg et } \\
\text { al, } 1984^{24}\end{array}$ & $\begin{array}{l}\text { Retrospective } \\
\text { population- } \\
\text { based case- } \\
\text { control study. }\end{array}$ & $\begin{array}{l}160 \text { cases of } \\
\text { glioblastoma and } \\
125 \text { population } \\
\text { controls, known } \\
\text { but not related to } \\
\text { the cases, }\end{array}$ & $\begin{array}{l}\text { Severe head } \\
\text { injuries were those } \\
\text { resulting in skull } \\
\text { fracture or } \\
\text { concussion } \\
\text { followed by a }\end{array}$ & 1977 to 1981 & None. & $\begin{array}{l}\text { RR all trauma } \\
2.1 \text { (1.1 to } 4.0 \text {, } \\
35)\end{array}$ & 5 \\
\hline
\end{tabular}




\begin{tabular}{|c|c|c|c|c|c|c|c|}
\hline Reference & Study Type & $\begin{array}{l}\text { Study } \\
\text { Population }\end{array}$ & Traumatic event & $\begin{array}{l}\text { Case } \\
\text { ascertainment }\end{array}$ & $\begin{array}{l}\text { Factors } \\
\text { accounted for in } \\
\text { analysis }\end{array}$ & $\begin{array}{l}\text { RR }(95 \% \mathrm{Cl}, \\
\text { number of } \\
\text { (exposed) } \\
\text { cases) }\end{array}$ & $\begin{array}{l}\text { Quality } \\
\text { Score } \\
\text { (NOS) }\end{array}$ \\
\hline & & $\begin{array}{l}\text { matched on sex, } \\
\text { age and area of } \\
\text { residence }\end{array}$ & $\begin{array}{l}\text { complication; Mild } \\
\text { head trauma } \\
\text { included } \\
\text { concussion or brief } \\
\text { loss of } \\
\text { consciousness with } \\
\text { no complications. }\end{array}$ & & & & \\
\hline $\begin{array}{l}\text { Ahlbom et al, } \\
1986^{18}\end{array}$ & $\begin{array}{l}\text { Hospital- and } \\
\text { population- } \\
\text { based case- } \\
\text { control study }\end{array}$ & $\begin{array}{l}79 \text { astrocytoma } \\
\text { cases with } 197 \\
\text { unmatched } \\
\text { clinical controls } \\
\text { having a } \\
\text { diagnosis of } \\
\text { meningioma, }\end{array}$ & $\begin{array}{l}\text { Head injuries not } \\
\text { within } 5 \text { years of } \\
\text { tumour }\end{array}$ & 1980 to 1981 & None & $\begin{array}{l}\text { Astrocytoma } \\
1.6 \text { (0.7 to } 3.9, \\
12 \text { ) (population } \\
\text { controls) } \\
1.2 \text { (0.6 to } 2.5, \\
12) \text { (clinical } \\
\text { controls) }\end{array}$ & 4 \\
\hline
\end{tabular}




\begin{tabular}{|c|c|c|c|c|c|c|c|}
\hline Reference & Study Type & $\begin{array}{l}\text { Study } \\
\text { Population }\end{array}$ & Traumatic event & $\begin{array}{l}\text { Case } \\
\text { ascertainment }\end{array}$ & $\begin{array}{l}\text { Factors } \\
\text { accounted for in } \\
\text { analysis }\end{array}$ & $\begin{array}{l}\text { RR }(95 \% \mathrm{Cl} \text {, } \\
\text { number of } \\
\text { (exposed) } \\
\text { cases) }\end{array}$ & $\begin{array}{l}\text { Quality } \\
\text { Score } \\
\text { (NOS) }\end{array}$ \\
\hline & & $\begin{array}{l}\text { pituitary adenoma } \\
\text { or cerebral } \\
\text { aneurysm and } 92 \\
\text { population } \\
\text { controls matched } \\
\text { on age, sex and } \\
\text { location of } \\
\text { residence. }\end{array}$ & & & & & \\
\hline $\begin{array}{l}\text { Carpenter et } \\
\text { al, } 1987^{20}\end{array}$ & $\begin{array}{l}\text { Nested case- } \\
\text { control study of } \\
\text { brain cancer in } \\
\text { two nuclear } \\
\text { facilities }\end{array}$ & $\begin{array}{l}82 \text { cases and } 328 \\
\text { controls matched } \\
\text { on race, sex, } \\
\text { facility, year of } \\
\text { birth and year of } \\
\text { hire }\end{array}$ & $\begin{array}{l}\text { Head injury (from } \\
\text { occupational health } \\
\text { records) }\end{array}$ & 1943 to 1979 & $\begin{array}{l}\text { Socioeconomic } \\
\text { status }\end{array}$ & $\begin{array}{l}0.9(0.2 \text { to } 4.2, \\
2)\end{array}$ & 4 \\
\hline
\end{tabular}




\begin{tabular}{|c|c|c|c|c|c|c|c|}
\hline Reference & Study Type & $\begin{array}{l}\text { Study } \\
\text { Population }\end{array}$ & Traumatic event & $\begin{array}{l}\text { Case } \\
\text { ascertainment }\end{array}$ & $\begin{array}{l}\text { Factors } \\
\text { accounted for in } \\
\text { analysis }\end{array}$ & $\begin{array}{l}\text { RR }(95 \% \mathrm{Cl} \text {, } \\
\text { number of } \\
\text { (exposed) } \\
\text { cases) }\end{array}$ & $\begin{array}{l}\text { Quality } \\
\text { Score } \\
\text { (NOS) }\end{array}$ \\
\hline $\begin{array}{l}\text { Burch et al, } \\
1987^{19}\end{array}$ & $\begin{array}{l}\text { Hospital-based } \\
\text { case-control } \\
\text { study }\end{array}$ & $\begin{array}{l}215 \text { cases of } \\
\text { glioma ad } 215 \\
\text { non-cancer } \\
\text { hospital controls } \\
\text { matched on age, } \\
\text { sex area of } \\
\text { residence, year of } \\
\text { birth, year of } \\
\text { diagnosis/death }\end{array}$ & $\begin{array}{l}\text { Brain injury or } \\
\text { accident }\end{array}$ & 1977 to 1981 & None & $\begin{array}{l}\text { RR 2.51 (2.09, } \\
3.02) \\
\text { RR restricted } \\
\text { to accidents } \\
\text { requiring } \\
\text { medical } \\
\text { attention } 1.20 \\
(0.88 \text { to } 1.64)\end{array}$ & 4 \\
\hline $\begin{array}{l}\text { Preston-Martin } \\
\text { et al, } 1989^{28}\end{array}$ & $\begin{array}{l}\text { Population- } \\
\text { based case- } \\
\text { control study }\end{array}$ & $\begin{array}{l}272 \text { males with } \\
\text { primary brain } \\
\text { cancer and } 272 \\
\text { controls matched } \\
\text { on age, sex, race }\end{array}$ & $\begin{array}{l}\text { Head injury } 20 \\
\text { years or more } \\
\text { before diagnosis } \\
\text { resulting in a } \\
\text { medical visit, loss }\end{array}$ & 1998-1984 & None & $\begin{array}{l}\text { Glioma } 0.8(0.5 \\
\text { to } 1.3,202) \\
\text { Meningioma } \\
2.3(1.1 \text { to } 5.4 \text {, } \\
70)\end{array}$ & 4 \\
\hline
\end{tabular}




\begin{tabular}{|c|c|c|c|c|c|c|c|}
\hline Reference & Study Type & $\begin{array}{l}\text { Study } \\
\text { Population }\end{array}$ & Traumatic event & $\begin{array}{l}\text { Case } \\
\text { ascertainment }\end{array}$ & $\begin{array}{l}\text { Factors } \\
\text { accounted for in } \\
\text { analysis }\end{array}$ & $\begin{array}{l}\text { RR }(95 \% \mathrm{Cl} \text {, } \\
\text { number of } \\
\text { (exposed) } \\
\text { cases) }\end{array}$ & $\begin{array}{l}\text { Quality } \\
\text { Score } \\
\text { (NOS) }\end{array}$ \\
\hline & & $\begin{array}{l}\text { and area of } \\
\text { residence }\end{array}$ & $\begin{array}{l}\text { of consciousness } \\
\text { or dizziness }\end{array}$ & & & $\begin{array}{l}\text { A significant } \\
\text { increasing } \\
\text { exposure } \\
\text { response was } \\
\text { seen for } \\
\text { number of } \\
\text { serious injuries } \\
\text { for } \\
\text { meningioma }\end{array}$ & \\
\hline $\begin{array}{l}\text { Codd et al, } \\
1990^{22}\end{array}$ & $\begin{array}{l}\text { Population- } \\
\text { based case- } \\
\text { control study }\end{array}$ & $\begin{array}{l}100 \text { cases of } \\
\text { glioma and } 200 \\
\text { population } \\
\text { controls matched } \\
\text { on age and sex }\end{array}$ & Head trauma & 1950 to 1977 & None & $\begin{array}{l}1.7(0.5 \text { to } 6.9 \text {, } \\
4)\end{array}$ & 6 \\
\hline
\end{tabular}

$-33-$ 


\begin{tabular}{|c|c|c|c|c|c|c|c|}
\hline Reference & Study Type & $\begin{array}{l}\text { Study } \\
\text { Population }\end{array}$ & Traumatic event & $\begin{array}{l}\text { Case } \\
\text { ascertainment }\end{array}$ & $\begin{array}{l}\text { Factors } \\
\text { accounted for in } \\
\text { analysis }\end{array}$ & $\begin{array}{l}\text { RR }(95 \% \mathrm{Cl}, \\
\text { number of } \\
\text { (exposed) } \\
\text { cases) }\end{array}$ & $\begin{array}{l}\text { Quality } \\
\text { Score } \\
\text { (NOS) }\end{array}$ \\
\hline $\begin{array}{l}\text { Schlehofer et } \\
\text { al, 199232 }\end{array}$ & $\begin{array}{l}\text { Population- } \\
\text { based case- } \\
\text { control study }\end{array}$ & $\begin{array}{l}226 \text { cases of } \\
\text { primary brain } \\
\text { cancer with } 418 \\
\text { controls } \\
\text { frequency } \\
\text { matched on age } \\
\text { and sex from } \\
\text { same area }\end{array}$ & $\begin{array}{l}\text { Head injury } \\
\text { involving } \\
\text { consultation with a } \\
\text { doctor at least } 5 \\
\text { years prior to } \\
\text { interview }\end{array}$ & 1987 to 1988 & $\begin{array}{l}\text { None, although } \\
\text { multivariable } \\
\text { regression gave } \\
\text { same resultss }\end{array}$ & $\begin{array}{l}\text { All brain } \\
\text { cancer } 0.71 \\
(0.5 \text { to } 1.1,39) \\
\text { Glioma } 0.70 \\
(0.4 \text { to } 1.2,27) \\
\text { Meningioma } \\
0.52(0.3 \text { to } \\
1.0)\end{array}$ & 5 \\
\hline $\begin{array}{l}\text { Zampieri et al, } \\
1994^{33}\end{array}$ & $\begin{array}{l}\text { Hospital-based } \\
\text { case-control } \\
\text { study }\end{array}$ & $\begin{array}{l}195 \text { cases glioma } \\
\text { and } 195 \text { controls, } \\
\text { matched on age, } \\
\text { sex, date of } \\
\text { hospitalisation } \\
\text { and residence. }\end{array}$ & $\begin{array}{l}\text { Mild (brief loss of } \\
\text { consciousness) } \\
\text { and sever (loss of } \\
\text { consciousness of > } \\
1 \text { hour, } \\
\text { neurological }\end{array}$ & 1986 to 1988 & None & $\begin{array}{l}\text { Glioma } 0.7(0.3 \\
\text { to } 1.4,31)\end{array}$ & 4 \\
\hline
\end{tabular}




\begin{tabular}{|c|c|c|c|c|c|c|c|}
\hline Reference & Study Type & $\begin{array}{l}\text { Study } \\
\text { Population }\end{array}$ & Traumatic event & $\begin{array}{l}\text { Case } \\
\text { ascertainment }\end{array}$ & $\begin{array}{l}\text { Factors } \\
\text { accounted for in } \\
\text { analysis }\end{array}$ & $\begin{array}{l}\text { RR }(95 \% \mathrm{Cl} \text {, } \\
\text { number of } \\
\text { (exposed) } \\
\text { cases) }\end{array}$ & $\begin{array}{l}\text { Quality } \\
\text { Score } \\
\text { (NOS) }\end{array}$ \\
\hline & & $\begin{array}{l}\text { Controls had a } \\
\text { variety of non- } \\
\text { malignant } \\
\text { diagnoses }\end{array}$ & $\begin{array}{l}\text { deficits, epilepsy, } \\
\text { cranial fracture or } \\
\text { any neurosurgical } \\
\text { procedure) }\end{array}$ & & & & \\
\hline $\begin{array}{l}\text { Preston-Martin } \\
\text { et al, } 1998^{30}\end{array}$ & $\begin{array}{l}\text { Multi-centre } \\
\text { international } \\
\text { population- } \\
\text { based case- } \\
\text { control study }\end{array}$ & $\begin{array}{l}1178 \text { cases of } \\
\text { glioma; } 330 \\
\text { meningioma } \\
\text { cases and } 2236 \\
\text { population } \\
\text { controls, mixture } \\
\text { of individual and } \\
\text { frequency } \\
\text { matched on age, } \\
\text { and sex, with }\end{array}$ & $\begin{array}{l}\text { Medically treated } \\
\text { head injury }\end{array}$ & 1984 to 1992 & $\begin{array}{l}\text { None (multivariable } \\
\text { adjusted latency } \\
\text { analysis presented } \\
\text { in Table } 4 \text { of } \\
\text { paper) }\end{array}$ & $\begin{array}{l}\text { Male, } \\
\text { meningioma } \\
1.49(0.86 \text { to } \\
2.57,26) \\
\text { Female } \\
\text { meningioma } \\
0.83(0.54 \text { to } \\
1.28,33)\end{array}$ & 2 \\
\hline
\end{tabular}

$-35-$ 


\begin{tabular}{|c|c|c|c|c|c|c|c|}
\hline Reference & Study Type & $\begin{array}{l}\text { Study } \\
\text { Population }\end{array}$ & Traumatic event & $\begin{array}{l}\text { Case } \\
\text { ascertainment }\end{array}$ & $\begin{array}{l}\text { Factors } \\
\text { accounted for in } \\
\text { analysis }\end{array}$ & $\begin{array}{l}\text { RR }(95 \% \mathrm{Cl} \text {, } \\
\text { number of } \\
\text { (exposed) } \\
\text { cases) }\end{array}$ & $\begin{array}{l}\text { Quality } \\
\text { Score } \\
\text { (NOS) }\end{array}$ \\
\hline & & $\begin{array}{l}\text { some additionally } \\
\text { matched on race } \\
\text { and residence }\end{array}$ & & & & $\begin{array}{l}\text { Male glioma } \\
1.18(0.94 \text { to } \\
1.48,210) \\
\text { Female glioma } \\
1.03(0.42 \text { to } \\
2.55,87)\end{array}$ & \\
\hline $\begin{array}{l}\text { Hu et al, } \\
1998^{25}\end{array}$ & $\begin{array}{l}\text { Hospital-based } \\
\text { case-control } \\
\text { study }\end{array}$ & $\begin{array}{l}218 \text { cases of } \\
\text { glioma and } 436 \\
\text { individually- } \\
\text { matched controls } \\
\text { with non- } \\
\text { neoplastic or non- } \\
\text { neurological } \\
\text { disease, matched }\end{array}$ & $\begin{array}{l}\text { Head trauma } \\
\text { requiring medical } \\
\text { attention }\end{array}$ & 1989 to 1995 & $\begin{array}{l}\text { Income, education, } \\
\text { number of years } \\
\text { drinking liquor, } \\
\text { occupational } \\
\text { exposure, fruit and } \\
\text { vegetable } \\
\text { consumption. }\end{array}$ & $\begin{array}{l}5.90(.251 \text { to } \\
10.31,34)\end{array}$ & 5 \\
\hline
\end{tabular}




\begin{tabular}{|c|c|c|c|c|c|c|c|}
\hline Reference & Study Type & $\begin{array}{l}\text { Study } \\
\text { Population }\end{array}$ & Traumatic event & $\begin{array}{l}\text { Case } \\
\text { ascertainment }\end{array}$ & $\begin{array}{l}\text { Factors } \\
\text { accounted for in } \\
\text { analysis }\end{array}$ & $\begin{array}{l}\text { RR }(95 \% \mathrm{Cl} \text {, } \\
\text { number of } \\
\text { (exposed) } \\
\text { cases) }\end{array}$ & $\begin{array}{l}\text { Quality } \\
\text { Score } \\
\text { (NOS) }\end{array}$ \\
\hline & & $\begin{array}{l}\text { on age, sex and } \\
\text { area of residence }\end{array}$ & & & & & \\
\hline $\begin{array}{l}\text { Hu et al, } \\
1999^{26}\end{array}$ & $\begin{array}{l}\text { Hospital-based } \\
\text { case-control } \\
\text { study }\end{array}$ & $\begin{array}{l}218 \text { cases of } \\
\text { glioma and } 436 \\
\text { individually- } \\
\text { matched controls } \\
\text { with non- } \\
\text { neoplastic or non- } \\
\text { neurological } \\
\text { disease, matched } \\
\text { on age, sex and } \\
\text { area of residence }\end{array}$ & $\begin{array}{l}\text { Head trauma } \\
\text { requiring medical } \\
\text { attention }\end{array}$ & 1989 to 1996 & $\begin{array}{l}\text { Income, education, } \\
\text { occupational } \\
\text { exposure, fruit and } \\
\text { vegetable } \\
\text { consumption }\end{array}$ & $\begin{array}{l}16.36(5.45 \text { to } \\
49.12,33)\end{array}$ & 5 \\
\hline
\end{tabular}




\begin{tabular}{|c|c|c|c|c|c|c|c|}
\hline Reference & Study Type & $\begin{array}{l}\text { Study } \\
\text { Population }\end{array}$ & Traumatic event & $\begin{array}{l}\text { Case } \\
\text { ascertainment }\end{array}$ & $\begin{array}{l}\text { Factors } \\
\text { accounted for in } \\
\text { analysis }\end{array}$ & $\begin{array}{l}\mathrm{RR}(95 \% \mathrm{Cl} \text {, } \\
\text { number of } \\
\text { (exposed) } \\
\text { cases) }\end{array}$ & $\begin{array}{l}\text { Quality } \\
\text { Score } \\
\text { (NOS) }\end{array}$ \\
\hline $\begin{array}{l}\text { Monteiro et al, } \\
2006^{27}\end{array}$ & $\begin{array}{l}\text { Hospital-based } \\
\text { case-control } \\
\text { study }\end{array}$ & $\begin{array}{l}231 \text { adults with } \\
\text { primary brain } \\
\text { tumour and } 261 \\
\text { hospital controls } \\
\text { matched for } \\
\text { gender, age and } \\
\text { hospital } \\
\text { diagnosed with a } \\
\text { condition } \\
\text { unrelated to brain } \\
\text { tumours }\end{array}$ & $\begin{array}{l}\text { Head injury at least } \\
1 \text { year prior to } \\
\text { diagnosis (cases) } \\
\text { or hospitalisation } \\
\text { (controls) }\end{array}$ & 1999 to 2002 & $\begin{array}{l}\text { Age, gender, } \\
\text { schooling, } \\
\text { epilepsy, alcohol } \\
\text { consumption }\end{array}$ & $\begin{array}{l}\text { All brain } \\
\text { cancer } 1.49 \\
(1.03 \text { to } 2.15, \\
107) \\
\text { Glioma } 1.30 \\
(0.71 \text { to } 2.35, \\
31) \\
\text { Meningioma } \\
1.63(0.96 \text { to } \\
2.75,38)\end{array}$ & 6 \\
\hline $\begin{array}{l}\text { Gousias et al, } \\
2009^{23}\end{array}$ & $\begin{array}{l}\text { Population- } \\
\text { based case- } \\
\text { control study }\end{array}$ & $\begin{array}{l}56 \text { cases of } \\
\text { glioma; } 112 \\
\text { controls matched }\end{array}$ & Cranial trauma & Not defined & $\begin{array}{l}\text { Alcohol, smoking, } \\
\text { mobile phone use }\end{array}$ & $\begin{array}{l}3.74(0.30 \text { to } \\
47.29,41)\end{array}$ & 4 \\
\hline
\end{tabular}




\begin{tabular}{|l|l|l|l|l|l|l|l|}
\hline Reference & Study Type & $\begin{array}{l}\text { Study } \\
\text { Population }\end{array}$ & Traumatic event & Case & Factors & RR (95\% Cl, & Quality \\
ascertainment & accounted for in \\
analysis & $\begin{array}{l}\text { number of } \\
\text { (exposed) } \\
\text { (NOS) }\end{array}$ \\
\hline & & $\begin{array}{l}\text { on age, sex and } \\
\text { area of residence }\end{array}$ & & & & & \\
\hline
\end{tabular}


Figure 1 - PRISMA Diagram

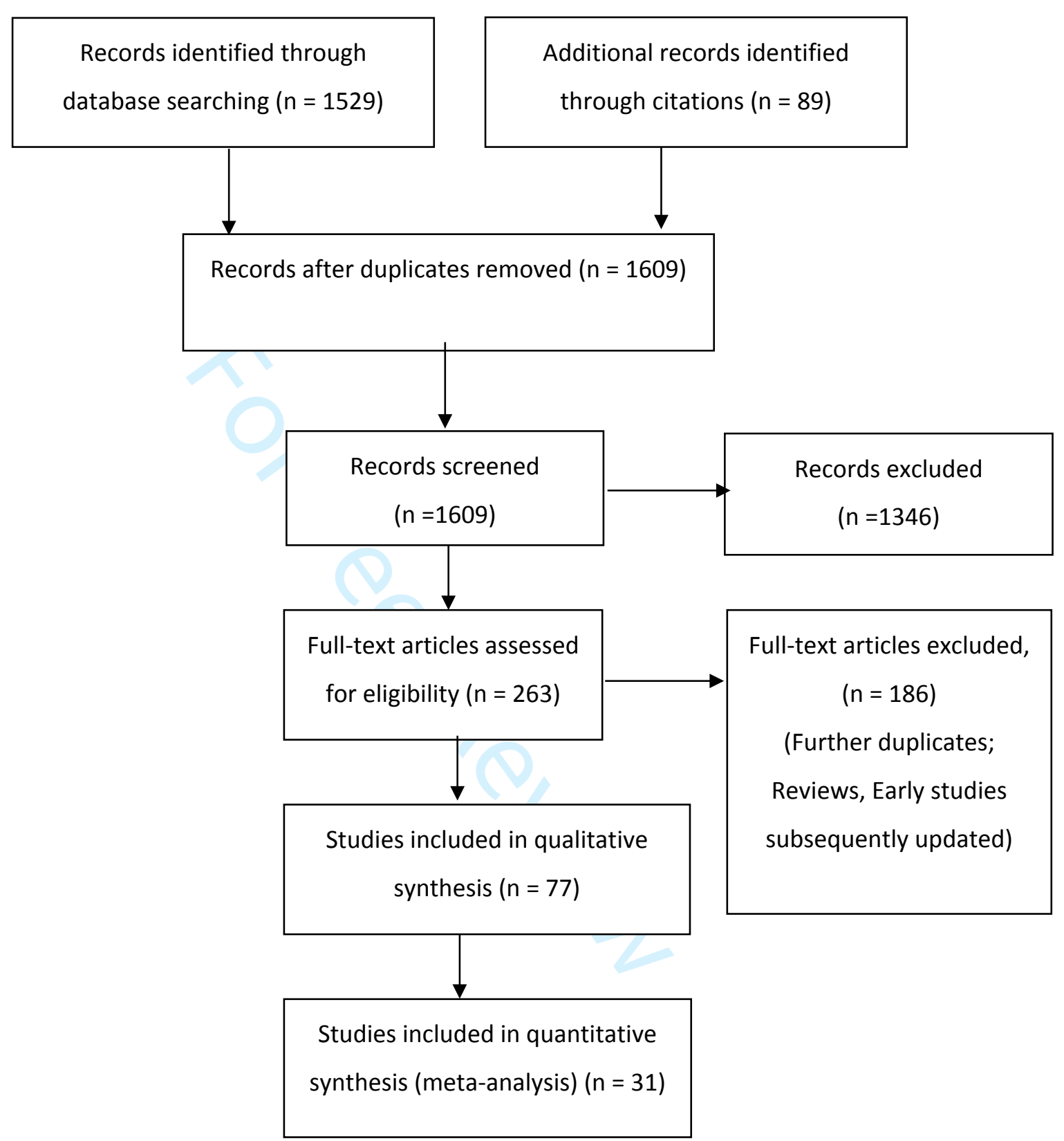


Figure 2 - Random effects meta-analysis for traumatic brain injury and brain cancer

\section{TBI \& brain cancer - Random effects}

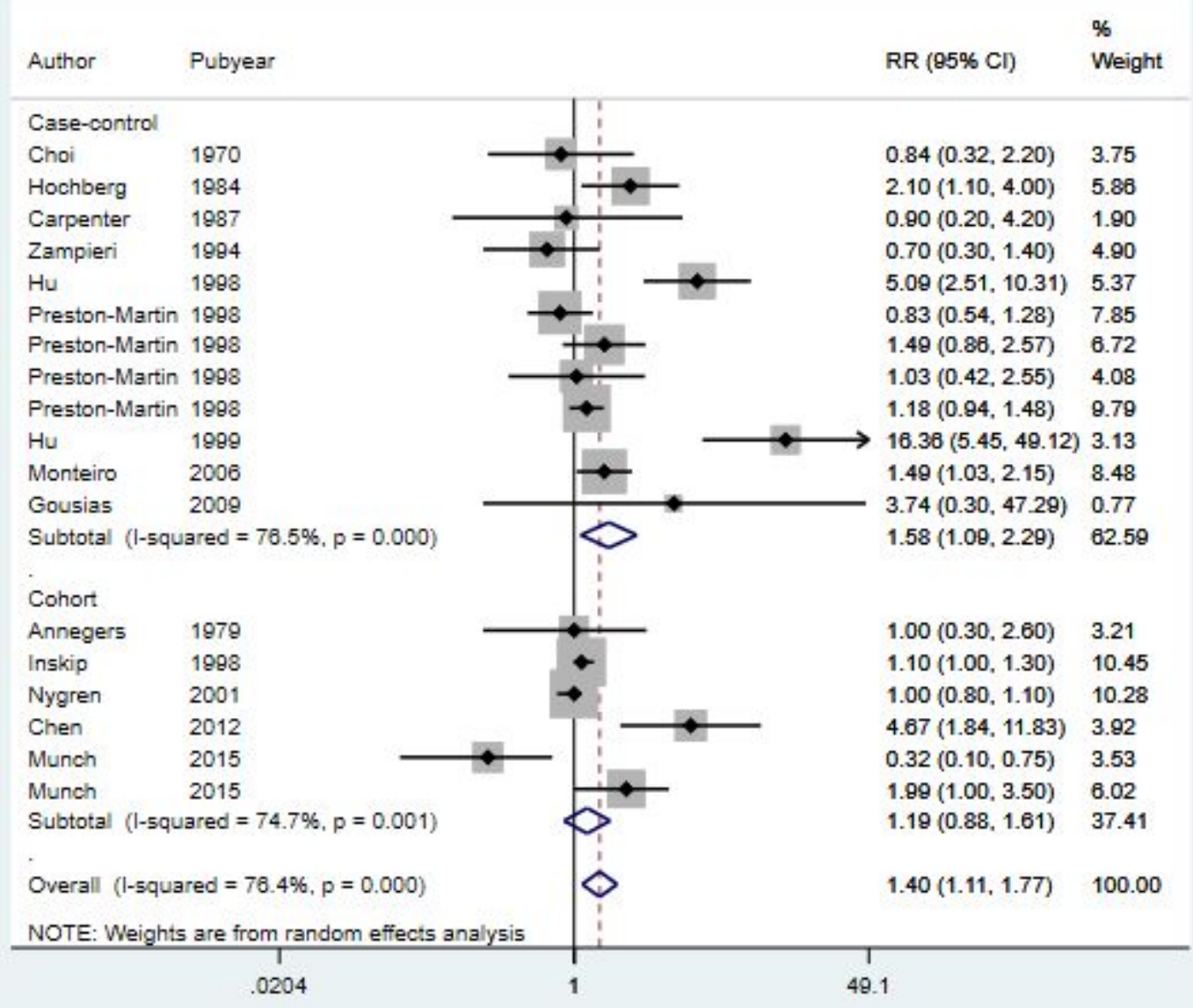


Figure 3 - Funnel plot for brain cancer meta-analysis

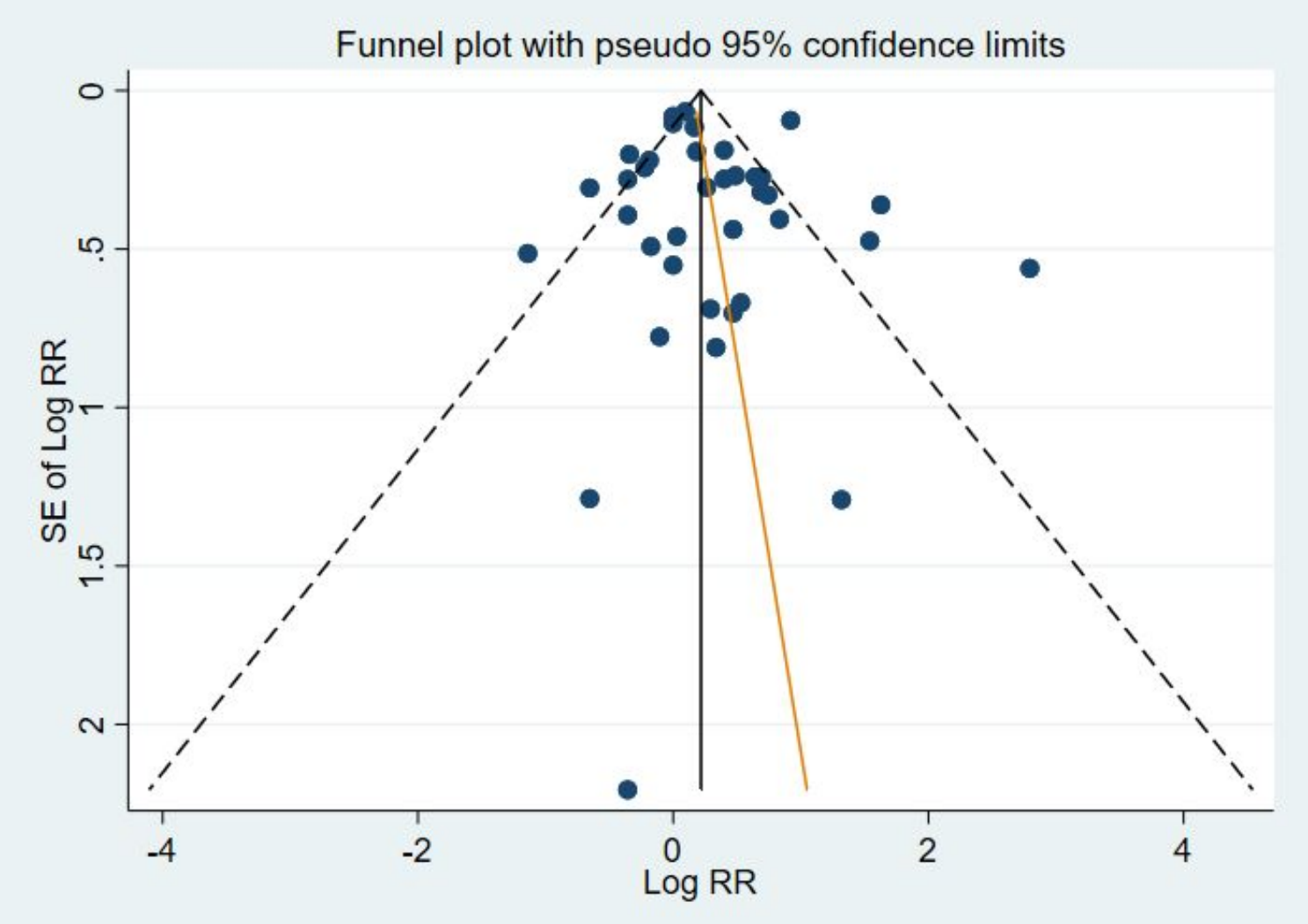

